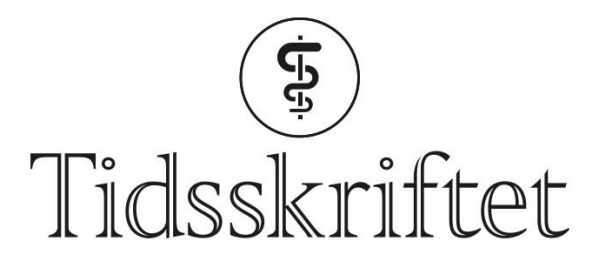

DEN NORSKE LEGEFORENING

\title{
Kan schistosomiasis utryddes?
}

FRA ANDRE TIDSSKRIFTER

KRISTOFFER BRODWALL

Barne- og ungdomsklinikken

Haukeland universitetssjukehus

Nasjonale program med medikamentell massebehandling reduserer forekomsten av schistosomiasis.

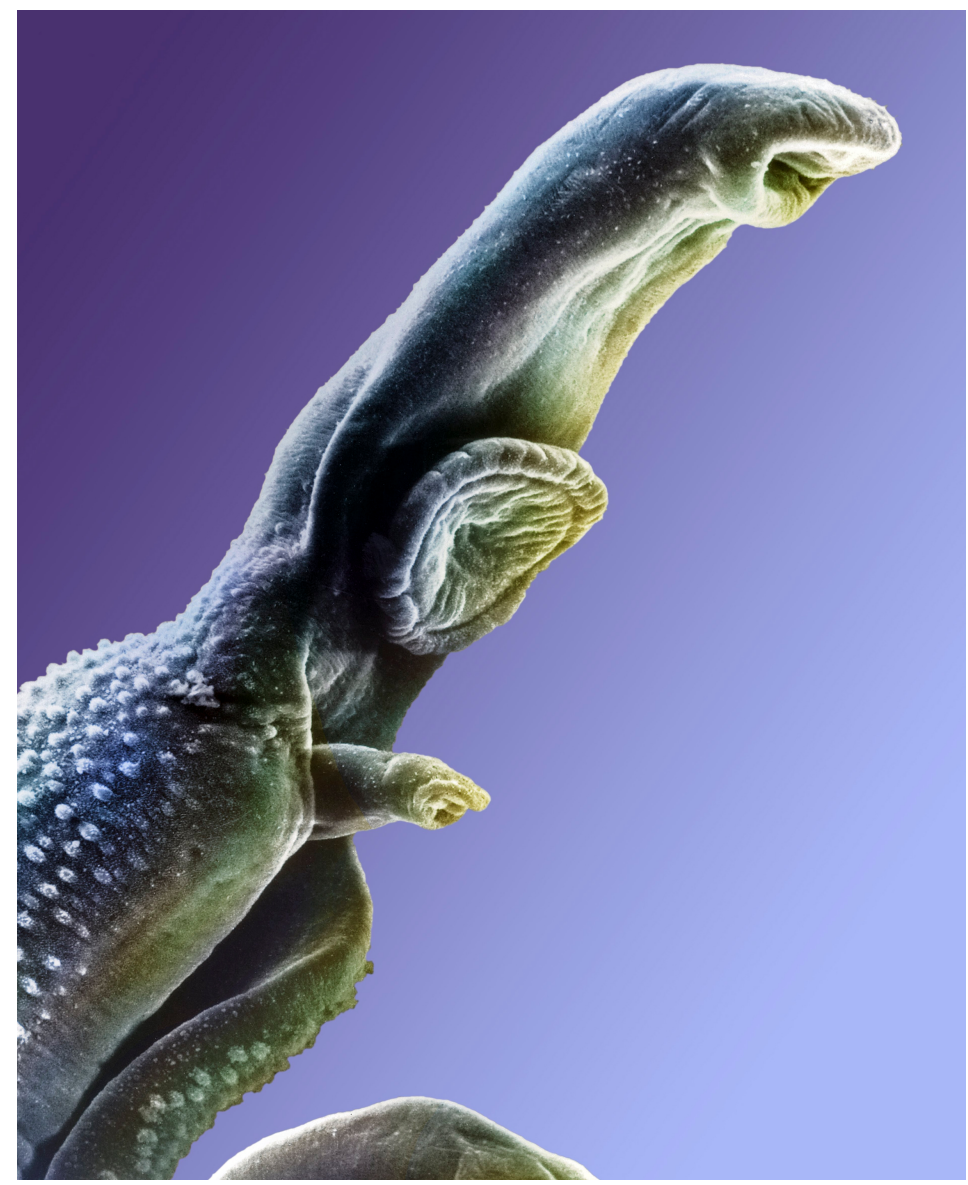

Illustrasjon: Science photo library/NTB Scanpix

Schistosoma er en slekt parasitter som kan sette seg i tarmen (S. mansoni) eller urinveiene (S. haematobium) hos mennesker. Parasittenes egg skilles ut med avføring eller urin og har et mellomstadium i ferskvannssnegler, før de infiserer nye mennesker gjennom huden.

Globalt er mer enn 140 millioner mennesker rammet, hovedsakelig i Afrika sør for Sahara. Schistosomiasis kan gi feber, anemi, dårlig vekst og irreversibel organskade. 
Verdens helseorganisasjon (WHO) har ambisjon om å utrydde schistosomiasis innen 2025, og status for dette prosjektet er nylig evaluert (1). Den anbefalte intervensjonen er regelmessig massebehandling med prazikvantel. Dette legemidlet gis til skolebarn i 5-15 års alder, siden den aldersgruppen har høyest infeksjonsbyrde og dessuten er lett å nå gjennom skolene. Den lokale forekomsten av schistosomiasis bestemmer hyppigheten av massebehandlingen: I områder der mindre enn 10 \% av befolkningen er smittet, gis massebehandling hvert 3. år, der 10-49\% er smittet, gis behandlingen hvert 2. år, og der over 50 \% er smittet, gis behandlingen årlig.

Den aktuelle studien baserer seg på data fra nasjonale kontrollprogram i ni land. Disse landene innførte sine kontrollprogram på forskjellige tidspunkter i perioden 2003-12. Ved oppstart varierte forekomsten av S. mansoni fra $2 \%$ til $45 \%$ og forekomsten av S. haematobium fra $10 \%$ til $82 \%$. Til tross for denne variasjonen oppnådde alle landene med unntak av Niger det delmålet som WHO definerer som kontroll, dvs. en forekomst på mindre enn $5 \%$, allerede etter én behandlingsrunde. I tre land oppnådde man etter tre behandlingsrunder det WHO definerer som eliminasjon, dvs. en forekomst på mindre enn 1 \% i befolkningen.

\section{LITTERATUR:}

1. Deol AK, Fleming FM, Calvo-Urbano B et al. Schistosomiasis - assessing progress toward the 2020 and 2025 global goals. N Engl J Med 2019;381: 2519-28. [PubMed][CrossRef]

Publisert: 21. februar 2020. Tidsskr Nor Legeforen. DOI: 10.4045/tidsskr.20.0024

(C) Tidsskrift for Den norske legeforening 2020. Lastet ned fra tidsskriftet.no 